\title{
The Effects of High Bride-Price on Marital Stability
}

\author{
Sambe, Ngutor ${ }^{1}$; Avanger, Moses Yandev ${ }^{2}$; Agba, Solomon Arumun ${ }^{3}$ \\ Department of Sociology, University of Mkar, Mkar, Benue state, Nigeria \\ Department of Sociology, University of Mkar, Mkar, Benue state, Nigeria \\ Department of Sociology, University of Mkar, Mkar, Benue state, Nigeria
}

\begin{abstract}
The thrust of the paper is to determine the effects of high bride price on marital stability. This is hinged on the fact that there is a persistent escalation of bride price with its associated repercussionon marriages in African societies. The specific objectives are, to identify the factors which determine high bride price among families; to investigate the effects of high bride price on marital stability; and to develop policy recommendations. Secondary data were used as source of information. It was discovered that high bride price affects the stability of marriages through precipitation of domestic violence, poverty especially among young couples, dehumanization of the women and increased propensity for divorce. The study concludes that high bride price has negative effect on marital stability. Recommendations made are that Non State Actors should carryout advocacy programmes that would stop escalation of bride-price or stabilize it; the Traditional authorities should work on their subjects in terms of creating awareness and advising their subjects on serious dangers of high bride price on marital stability and there should be a maximum amount of money or materials that should be fixed for payment as bride price no matter the socio-economic status of the bride or groom.
\end{abstract}

Keywords:Bride-price, Marriage, Marital stability, domestic violence, divorce

\section{Introduction}

Most societies, at some point in their history, have been characterized by payments at the time of marriage. Such payments typically go hand-in-hand with marriages arranged by the parents of the respective spouses. These marriage payments come in various forms and sizes. Brideprice occurs in two-thirds of societies recorded in Murdock's (1967) World Ethnographic Atlas of 1167 preindustrial societies.

Bride price or bride wealth is used to validate customary marriages, is a common practice in many African societies. Typically, bride price consists of contract where material items (often cattle, pig, or other animals) or money are paid by the groom to the bride's family in exchange for the bride for the labour and her capacity to produce children (Oguli, Oumo, 2004). This practice of bride price has different names in different countries and regions of Africa. In among the Zulus, it is known as Lobola, the Tiv of central Nigeria call it kem. Increasingly in urban areas, the practice is changing so that money (rather than animal) is more commonly given inform of non-refundable gifts. However, in rural (though varying by ethnic/tribal group, tradition and culture), more traditional bride price practices remain traditionally common and tend to be accepted as cultural norm.

In the past, tradition of bride price is believed to have operated beneficially to give formal recognition to marriages and protect wives against abuse, stabilize the partnership and to join the two families together. Today, however the practice appears to have become commercialized and to have lost much of its traditional value in many instances. Bride price can now appear to be buying o a wife as a commodity which results to abuse of women if she does not fulfill her value or she attempts to leave the bride cannot be repaid (Matembe 2004, Ndira, 2004). Domestic violence, abuse of women's rights, poverty among newly married couples, divorces etc have been found to be associated with high bride price (Matembe 200, Sekagya 2004, Oguli Oumo 2004). These have serious implication on the stability of families especially newly married couples.

In third world countries, commercialization of bride price or high bride wealth is a practice that tends to be common among ethnic/tribal groups or cultures. Socio- economic variables such as level of education of the bride, social status of bride family etc have become deciding factors in determining bride price. In such cases where the bride attains high education or is a working class, bride price tends to be escalated. The groom or his families are expected to pay heavily in these circumstances. Further, most ethnic groups consider female child to be of highly value commodity, which when invested into properly can guarantee high financial or economic reward. Consequently the groom or his family is required to buy the commodity at the highest price so as to ensure or gain profit (Obotu, 2012)

The high bride price practices which has prevailed among societies and cultures today is not unconnected with the dysfunctional nature of the modern family. High bride price has serious implication on the marital instability. This is reflected in high rates of divorce, domestic violence, poverty among newly married syndrome, violation of women's rights. 
This study is primarily interested in the investigation of the effects of high bride price on marital stability.

\section{Objectives of the study}

The general objective of the study is to determine the effects of high bride price on marital stability. Specific objectives are as follows:

(a) To identify the factors which determine high bride price among families

(b) To investigate the effects of high bride price on marital stability

(c) To develop policy recommendations

\section{Literature Review}

\section{The Concept of Bride price}

The concept of bride-price has been conceptualized by many scholars and writers of marriage payments. Bride price may be defined as payment made in kind, cash or material as demanded by custom of a group by a groom or his family to the family of the bride who in order to make the union legitimate. According to Oguli Oumo (2004), bride-price consists of a contract where material items (often cattle or other animals) or money are paid by the groom to the bride's family in exchange for the bride, her labour and her capacity to produce children. Rakhimdinova (2005) defined bride-price as the amount of money or property or wealth paid by the groom or his family to the parents of the woman upon marriage of their daughter to the groom. The agreed bride price is generally intended to reflect the perceived value of the girl or young woman. In the conception of Alupo (2004) involves payment in cash or property by husband and his family to the Bride's family. It is symbolic of friendship but in actual fact it's the transfer of productive and reproductive service to the man's family. To Meekers (1992) bride-price (lobola), common in South African marriages, symbolizes the transfer of the right of the girl's sexual and economic services to the husband.

Radcliffe-Brown (1987) also define bride-price as the situation where payment of goods and services is made by the bridegroom to the bride's kin as an essential part of the establishment of legality of marriage. Wegh (2003) conceptualized brie-price in the Tiv perspective. To him, bride-price (kem) refers to the act of acquiring bit by bit and accumulation of an item... an element of saving. Akiga (1939) it is an expression of intent to make exchange, to impose a cash payment of bride-wealth. Anyebe (1985) in his analysis of bride price expatiates that bride-price (bride-wealth) makes marriage legal and establishes the legitimacy of children. Also it is a compensation for loss to the woman's family of one of its members, a potential child bearer, it is marriage insurance to stabilize relationship and protect the wife.

\section{The Prevalence of Bride-Price}

The custom of bride price dates back as far as 3000 BCE. The ancient civilizations of Egyptians, Mesopotamians, Hebrews, Aztecs, and Incas all used bride price (Quale, 1988). The Germanic tribes, who date from $2000 \mathrm{BCE}$ and ruled western Europe from the 600 to $1000 \mathrm{CE}$, required bride price for a marriage to be legal (Hughes, 1985). A valid marriage contract in Islamic law required a form of bride-price (Bianquis, 1996). Such transactions are associated with the Maghreb of the early Middle Ages, Bedouin tribes of the Middle East, and countries previously under the Ottoman Empire such as Iraq, Syria, Egypt, Turkey, Iran, Albania, and Afghanistan (Rapoport, 2000; Quale, 1988). Classical China required the negotiation of a bride price for the validity of marriage, and these transfers continue to be the norm in many rural areas today (Ebrey, 1993). China also seems to be one of the few examples where bride price and dowry coexist, with the bride price being compulsory and the dowry, which is more voluntary in nature, typically financed with a return portion of the bride price (Engel, 1984). Taiwan also seems to follow this traditional Chinese practice of exchanging marriage payments in both directions (Parish and Willis, 1993). Other countries in Southeast Asia, such as Thailand, Indonesia, and Burma, seem to only transfer bride prices (Cherlin and Chamratrithirong, 1988; Spiro, 1975).

Bride prices are most prevalent in Africa; more than 90 percent of sub-Saharan societies traditionally made such marriage payments (Murdock, 1967; Goody, 1973). Bride prices remain prevalent in the rural areas of China, but rare in urban Chinese environments. The majority of urban marriages in Thailand seem to make monetary transfers. It was also common in the major cities of Egypt, Syria, Zaire, Uganda, and Iran at least until the 1980s. Recent data from Uganda and Turkey indicate some abatement, both in rural and urban areas.

\section{The concept of Marriage}

Plethora of views has been advanced by scholars regarding marriage. According to Westermarck (1921) marriage is a more or less durable connection between male and female lasting beyond the mere act of propagation till after the birth of the offspring. Future of Marriage in West Civilization (1956) rejects the definition. It therefore sees marriage as a relationship $\mathrm{f}$ one or more men to one or more women that is recognized by law or custom. To Anthropology Handbook, Notes and Queries (1951) the concept is seen as a 
union between man and woman such that children born by the woman are the recognized legitimate offspring of both parents. Murdock (1949) marriage exists when those who share a sexual union also share an economic cooperation. Marriage is to be found where the economic and sexual aspects are united into one relationship. This definition is vague and limited because it sees economic cooperation as the only factor that is universal and common to marriage universally.

To Goodenough (1970) marriage is a transaction an resulting contract in which a person (male or female corporate or individual, in person or by proxy) establishes a continuing claim to the right of sexual access to a woman-this right having priority over rights of sexual access others currently have or may subsequently acquire in relation to her (except in a similar transaction) until the contract resulting from the transaction- and in which the woman involved is eligible to bear children. The definition explains that marriage can occur where a woman may marry another woman, exercising the right to sire children through someone acting in her name. It also make room for group of relatives or brothers s corporation taking a woman as their corporate wife and allows for ghost marriage of the Nuer which a man takes wife on behalf of the dead brother or son for who he acts as proxy. This definition tries to include all that may be seen as marriage no matter the socio-cultural context.

In the conception of Anyebe (1985) marriage is a voluntary union of one man and a woman or women to the exclusion of others. This union extends beyond the life of the man but terminates substantially at the death of the woman. This definition of marriage is based on the customary law of Federal Republic of Nigeria. This conception is more vivid in reference to polygamy.

Fox (1967) have described the importance of marriage: Kinship and marriage are about the basic facts of life. They are about birth and copulation, and death, the eternal round that seemed to depress the poet but which excites the anthropologist. Copulation produces the relation between mates which is the foundation of marriage and parenthood. Birth produces children and long lasting mother-child bond, the most fundamental and basic of bonds.

Peters and Edward (1917) using Canon 1055 of the 1983 Code describes marriage as The marriage covenant, by which a man and a woman establish between themselves a partnership of their whole life, and which of its own very nature is ordered to the well-being of the spouses and to the procreation and upbringing of children, has between the baptised, been raised by Christ the Lord to the dignity of a sacrament. It should be added that Vatican II was extremely influential in changing how marriage was defined and viewed. This is a much-changed view from the previous Code of Canon Law (1917 Pio-Benedictine Code of Canon Law6) when marriage was defined in Canon 1013:1 as The primary end of marriage is the procreation and education of children, the secondary [end] is mutual support and a remedy for concupiscence. The essential properties of marriage are unity and indissolubility, which in Christian marriage obtain special firmness by reason of the sacrament.

Wegh (2003) also noted that bride-price helps in stabilizing of family alliance. The idea here seems to be that in the fear paying back bride price after dissolution of a marriage may lead the family of the woman to do its part in ensuring that marriage is successful. He observe that among the Tiv, the implication for children born in a situation where bride-wealth has not been paid is that such children are regarded as belonging to the woman's family rather than the family of the man. For the paper, marriage could be conceptualized as a legal or legitimate unification of a man and a woman for the purpose of performing basic family functions, which is expected to endure for the rest of their lives.

\section{FACTORS DETERMININGHIGH BRIDE-PRICE}

Women generally join the household of their groom at the time of marriage, brideprice is typically considered to be the payment a husband owes to a bride's parents for the right to her labor and reproductive capabilities. The amount of brideprice required has usually been rather uniform throughout society, where the size is linked directly to the number of rights which are transferred and not to the wealth level of the families involved (Quale, 1988; Goody, 1973). The studies of Tapper (1981) for Afghanistan, Zhang (2000) for rural China, and Mulder (1995) for Kenya suggest that the amount of brideprice is relatively constant across families of different income levels. Evidence from Kenya suggests that brideprice amounts also do not vary with the rank of the wife in polygynous marriages. Ancient brideprice was often considered a direct payment for a bride's virginity.

The amount was fixed at a relatively constant level in early legal codes of the Germanic tribes (Hughes, 1985) and in Hebrew law (Alvarez-Pereyre and Heymann, 1996). Among Bedouin tribes, where marriage to paternal cousins was most common, the brideprice was often larger if the bride married a more distant relative because in that case, the groom gained rights to a woman and children from a more distant lineage (Bianquis, 1996). This relationship was similarly found by Papps (1983), who studied brideprices in a 1920s Palestinian village, and Kressler (1977), who looked at data from 1964-1975 among Bedouin living in Israeli towns. The amount of brideprice can also depend on the expected number of children a woman will bear. For example, a 
divorced woman who already has children will receive a lower brideprice, whereas women who reach puberty earlier receive a higher price (Dekker and Hoogeveen, 2002; Mulder, 1995).

In sub-Saharan Africa, a central purpose of the brideprice is to create an alliance between kinship groups (Dekker and Hoogeveen, 2002; Ekong, 1992). As a result, raising the brideprice is often the responsibility of the groom's extended lineage group, with the principle contributions coming from his father, grandfather, and father's brothers, and with mother's brothers making small contributions. Likewise, since in this setting the entire lineage group has rights to a woman, the brideprice is distributed among many members of the bride's extended family. In this case, larger bride prices can arise with larger lineage groups.

Platteau and Gaspart (2007) in their study asserts that bride-price for educated women (defined as those who have completed their primary studies) significantly exceeds that observed for non educated women is easily explained in terms of the supply/demand framework since educated women are in scarce supply (they represent only $12.5 \%$ of the sample women). Yet, higher bride-prices for educated women are only observed for arranged marriages: in the case of love marriages, there is no statistically significant difference between the bride-prices paid for educated and non-educated women. To account for this differentiated result, the assumption of strategic behaviour is helpful. It, indeed, suggests the following interpretation: when educated women are involved in love marriages, in which they obviously have more leeway to assert their concerns, they are better able to influence their parents so as to prevent the bride-price from being set at a high level.

Wegh (2003) with reference to Tiv society said bride price escalation has been borne out of monetary economic praxis. In this praxis, money determines consumer power of the family. Parents spend a lot of money on the education of their children. More education means more years of parental care and heavier expenditure. In stringent economic circumstances, there is an inclination not only to conceive bride price in its legitimate function in marriage but also to see it as a kind of repayment of money spent on the training of daughters.

\section{THE EFFECTS OF HIGH BRIDE PRICE ON STABILITY OF MARRIAGES}

Studies on the effects of high bride price on marital stability abounds. Bloch and Rao (2002) studies in rural India showed that high bride price could affect marital stability. They presented a model whereby the husband hurts his wife's well-being in order to extract a payment from his in-laws where he feels the bride price was overpriced. Bloch and Rao rely on a signaling mechanism, in which the abandonment threat is made credible by resort to violence. The bride's family gives in to violent behaviour because it can only be committed by husbands willing to abandon their wife if their request is not satisfied. Thus, bride price was found precipitate violence which has high tendency to affect stability of marriages.

Writers of marriage payments have deliberated on the impact of high bride price on stability of marriages in Africa and other developing countries. Alupo (2004) have cited instances where Bride price is a major factor contributing to domestic violence in the relationships thereby threatening the stability of marriage in Uganda. Bride price is a commercial transaction with the marriage being valid only when bride -price has been paid but it has sometimes been seen as the basis for the claim that women are exchanged for goods as if they were commodities, normally there is bargaining between the parties concerned. To him, a lot of women in Uganda have suffered and had their rights violated because of bride price payment. This has implications on the stability of marriage in the area and elsewhere in the world. Once the man has paid Bride Price the woman is reduced to the status of property because the man has paid for her. She not only becomes part of the property but even what she works for becomes part of the husband's family property because they paid bride price. This affects women's freedom thereby affecting their marital stability.It forces a woman to live under an intolerable and hostile family environment subjects her to servitude and slave like conditions hence leading to violence against women, when the marriage breaks down.

Ansell (2001) argue that though marriage payments can take many different forms, no consensus exists on which of these forms, if any; will enhance the welfare of women. In theory, brideprice could be interpreted as explicit recognition and valuing of women's productivity and contribution to marriage; in practice, it often serves to limit women's control over their bodies. Both sexually and in terms of their labor, high brideprice has long been linked to domestic violence, owing to women's fear of returning to their natal home without being able to repay the brideprice. Bishai and Grossbard (2006) demonstrate that high brideprice increases the number of extramarital affairs for men, but decreases those of women. This extra-marital affairs increase the chance of marital problems in the family. Often the men do feel that woman has become his property hence heavy bride price paid on her head.

Rogers(2004) commenting on the bride -price and dehumanisation of women in Uganda, linked it to some violence against women which could destabilise marriages. To him, bride price is supposed to be a symbol or a token of appreciation to the family of the girl to be married off (the bride) and not meant to dehumanize women as property to be owned, sold and bought off in order to satisfy men's selfish desires and egos. However, bride price is being misused to abuse girls and women. Men tend to think that after paying the bride price women become their goods, services and personal property to be owned, mistreated and dumped when theyhave 
outlived their purpose and use. The conception produces a negative effect as the relationship between men and is affected.

Platteau and Gaspart (2007) studies in Senegal indicated that high bride-prices contribute to alienation of women and transform them into commodities or into their husband's slaves. They associate bride price withexpression that shows a deep-seated frustrations and intense suffering. Behind these expressions lies the fear that the husband and his family may resent high bride-prices because of the financial stress caused. The resentment lingers on when the bride-price is paid in installments and the husband or his family regret having agreed to an unbearable burden, especially if they find fault with the wife or daughter-in-law. In such conditions, the woman is exposed to a serious risk of harassment and ill-treatment by the husband and his relatives because she is considered to be the cause of the problems encountered by them. The conclusion of their study is that high bride-prices tend to affect the stability of marriages by alienating women, or driving husbands to harass and ill-treat their wife. In other words, men themselves are to some extent aware that women can be harmed under conditions of duress created by high bride-prices. While determining the bride-price for his daughter, a man could therefore consider the negative consequences that large sums can entail for her future well-being (Platteau and Gaspart, 2007).

In Uganda, Hague and Thiara (2009) wrote on the effect of high bride price on men which has serious implications on marital instability. They identified the effects of high bride-price on men in the interviews which were conducted with male respondents in the Members of the Public Interview data-set. The effects of high bride price on marital instability included poverty which the couples are forced enter into by way of incurring severe debt. They maintained that high bride price heaps huge pressure on young inexperienced men when they have no resources; and young people starting marriage and adult life in financial trouble as poverty has serious implications on stability of marriages. Hague and Thiara (2009) also commented on scenarios where high bride price led to the inability of the co-habitating man and woman to be separated due to non- payment of bride price, thus leading to divorce. They maintained that there were also issues around co-habiting, where parents had come to take their daughters back since bride-price was clearly not going to be paid, breaking up the new family. In other cases there was unhelpful interference in relationships by the parents if the agreed bride-price payment was incomplete:

\section{Conclusion}

\section{Conclusion And Recommendations}

Based on the findings acquired through the review of the literature, it could be concluded that high bride-price has detrimental effect on marital stability due to the fact that it increases the possibility of domestic violence as men consider women as their property bought at high prices, as a result leads to ill treatment which could affect marital relationships. Furthermore, high bride-price has the tendency to subject couples poverty especially newly marries ones as huge resources are been expended by the groom or his family leaving him stretched economically. Thuspoverty thus is a source of most marital problems marriages in modern societies.High bride price could also lead to marital desolation as most grooms cannot afford it, the resultant effects id the bride family taking their daughter back home.

\section{Recommendations}

The following recommendations have been drawn based on the above conclusion:

a. Non State Actors should carryout advocacy programmes that would stop escalation of bride-price or stabilize it.

b. The Traditional authorities should work on their subjects in terms of creating awareness and advising their subjects on serious dangers of high bride price on marital stability.

c. There should be a maximum amount of money or materials that should be fixed for payment as bride price no matter the socio-economic status of the bride or groom.

\section{References}

[1]. Alupo J, (2004) Bride Price And Gender Violence, A Paper Presented To The Participants At The International Conference On Bride Price And Development, Makerere University Kampala Uganda

[2]. Anderson, S. (2007) The Economics of Dowry and Bride-price; Journal of Economic Perspectives 21( 4) Fall 2007, PP 151-174

[3]. Anyebe, P.A (1985) Customary Law: The War Without Arms, Enugu: Forth Dimension Publishers.

[4]. Becker, G.S., (1974) “A Theory of Marriage: Part II”, Journal of Political Economy, Vol. 82, N², pp. S11-26.

[5]. Becker, G.S., (1981) A Treatise on the Family, Cambridge Mass.: Harvard University Press.

[6]. Bergstrom, T.C., (1996) "Economics in a Family Way", Journal of Economic Literature, Vol. 34, N 4, pp. $1903-1934$.

[7]. Bergstrom, T.C., (1997) "A Survey of Theories of the Family", in M.R. Rosenzweig and O. Stark (eds.), Handbook of Population and Family Economics -Vol. 1A, Amsterdam: Elsevier, pp. 21-79.Stark (eds.), Handbook of Population and Family Economics Vol. 1A, Amsterdam: Elsevier, pp. 21-79.

[8]. Bloch, F., and V. Rao, 2002, "Terror as a Bargaining Instrument: A Case Study of Dowry Violence in Rural India", American Economic Review, Vol. 92, N4, pp. 1029-1043.

[9]. Bridewealth, and Clan Exogamy, Current Anthropology, Vol. 38, (1), 1-23 
[10]. Dekker, M., and Hans H. (2002) “Bridewealth and Household Security in Rural Zimbabwe.” Journal of African Economics, 11(1): 114-45.

[11]. Ekong, J.M. (1992) Bridewealth, Women and Reproduction in Sub-Saharan Africa. Bonn: HolosVerlag.

[12]. Ensminger, J., and J. Knight, (1997) Changing Social Norms -Common Property;

[13]. Gaspart, F, Platteau, J(2007) Strategic Behaviour And Marriage Payments: Theory And Evidence From Senegal, Eudn/Wp 2007 03

[14]. Goode W. (1971). Force and Violence in the Family. Journal of Marriage and the Family, 33, 624- 636.

[15]. Goodenough, H (1970) Description in Cultural Anthropology, London: Cambridge University Press.

[16]. Goodenough, H (1970) Description in Cultural Anthropology, London: Cambridge University Press.

[17]. Goody, J. (1973) "Bridewealth and Dowry in Africa and Eurasia." In Bridewealth and Dowry, ed. Jack Goody and Stanley J. Tambiah, 1-58. Cambridge: Cambridge University Press.

[18]. Gratianus Collection Series; Code of Canon Law Annotated Second Edition. Midwest Theological Forum and Wilson and Lafleur Limitee.

[19]. Grossbard-Shechtman, S., (1993) On the Economics of Marriage: A Theory of Marriage, Labor and Divorce, Boulder: Westview Press.

[20]. Hague, G; Thiara, R (2009) Bride-Price, Poverty and Domestic Violence in Uganda, Final Report; An International Collaboration between MIFUMI Uganda Violence Against Women Research Group, University of Bristol, UK Centre for the Study of Safety and Well-being, University of Warwick, UK.

[21]. Hughes, D. O. (1985) "From Brideprice to Dowry in Mediterranean Europe." In TheMarriage Bargain: Women and Dowries in EuropeanHistory, ed. Marion A. Kaplan, 13-58. New York: Havorth Press.

[22]. Kressel, Giedon M. (1977) "Brideprice Reconsidered." Current Anthropology, 18(3): 441-58.

[23]. Lam, D., (1988) "Marriage Markets and Assortative Mating with Household Public Goods: Theoretical Results and Empirical Implications", Journal of Human Resources, Vol. 23, pp. 462-87.

[24]. Lundberg, S., and R.A. Pollak, (1996) "Bargaining and Distribution in Marriage", Journal of Economic Perspectives, Vol. 10, N 4, pp. $139-158$.

[25]. Matembe, M. (2004) The relationship between domestic violence and bride price, paper presented at the International Bride Price Conference, MP Mbarara and Pan African Parliamentarian, February, Kampala, Uganda.

[26]. Mulder, M. B. (1995) "Bridewealth and Its Correlates: Quantifying Changes over Time.” Current Anthropology, 36(4): 573-603.

[27]. Murdock, G (1949) Social Structure, New-York: Macmillan

[28]. Ndira, P. (2004) Bride Price: A Rights based view, paper presented at the International Bride Price Conference, February, Kampala, Uganda.

[29]. Obotu, F (2012) The Effects of High Bride Price on Marital Instability in Gboko Local Government Area, Benue State; Unpublished B.Sc Project, University of Mkar, Mkar Benue, Nigeria.

[30]. Oguli Oumo, M. (2004) Bride Price and Violence Against Women: the Case of Uganda, paper presented at the International Bride Price Conference, February, Kampala, Uganda.

[31]. Osuna, M. (2003) The MIFUMI Project Domestic Violence and Bride Price Referendum Project Baseline Survey Report: Attitudes to Bride price and its links to domestic violence and human rights abuse, TororoDistrict, Uganda,: MIFUMI.

[32]. Papps, I. (1983) “The Role and Determinants of Bride-Price: The Case of a Palestinian Village.” Current Anthropology, 24(2): 20315.

[33]. Peters, Dr Edward N The 1917 Pio-Benedictine Code of Canon Law in English with extensive scholarly apparatus. Ignatius Press 2001.

[34]. Platteau, J.P., and F. Gaspart, (2005) “The Perverse Effects of High Brideprices", Working Paper, Center for Research in the Economics of Development (CRED), University of Namur

[35]. Quale, R.G. (1988) A History of Marriage Systems. New York: Greenwood Press.

[36]. Rogers, N (2004) The Human And Economic Costs Of Bride Price In Buganda, A Paper Presented To The International Conference, Organized By Mifumi On Bride Price And Development From The 16th $-18^{\text {th }}$ At Makerere University, Kampala Uganda, February 2004

[37]. Tapper, N. (1981) “Direct Exchange and Brideprice: Alternative Forms in a Complex Marriage System.” Man, New Series, 16(3): $387-407$.

[38]. Wegh S.F (2003) Between Continuity and Change: Tiv Concept of Tradition and Modernity, Enugu: SNAAP Press Ltd.

[39]. Zhang, W. (2000) "Dynamics of Marriage Change in Chinese Rural Society in Transition: A Study of a Northern Chinese Village." PopulationStudies, 54(1): 57-69. 